\title{
Development of the Nickel-Refining Production at Norilsk Nickel Harjavalta Oy in GMK Norilsk Nickel
}

\author{
M. N. Naftal' ${ }^{a, ~ *}$, N. S. Kuznetsov ${ }^{b}$, S. S. Naboichenko ${ }^{c}$, K. A. Solntsev ${ }^{d}$, and V. A. Bryukvin ${ }^{d}$ \\ ${ }^{a}$ OOO NPP Qualitet, Moscow, Russia \\ ${ }^{b}$ Norilsk Nickel Harjavalta Oy, Harjavalta, Finland \\ ${ }^{c} U r F U$, Yekaterinburg, Russia \\ ${ }^{d}$ Baikov Institute of Metallurgy and Materials Science, Russian Academy of Sciences, Moscow, Russia \\ *e-mail: qualitetmet@mail.ru
}

Received July 18, 2018; revised September 17, 2018; accepted October 22, 2018

\begin{abstract}
As a result of the innovative solutions found due to the joint efforts of Russian and Finnish researchers, the recovery of nonferrous and precious metals in Norilsk Nickel Harjavalta was significantly increased (\%): the recovery of $\mathrm{Ni}$ was increased to 98.7 ; that of $\mathrm{Cu}$, to 99.5; Pt, to 99.6; and $\mathrm{Pd}$ to 99.6. Simultaneously, a copper cake (one of the main commercial products) of an improved composition, namely, (\%) $57-62 \mathrm{Cu},<3 \mathrm{Ni}, 8-11 \mathrm{Fe}$, was produced. The arsenic content in the copper cake was decreased from 1.5-2 to $0.15-0.3 \%$. The largest projects are as follows: stage-by stage implementation of a matte-free technology with simultaneous modification of the matte line for processing converter matte; the development of a jarosite technology of iron deposition from a nickel solution, which decreased the irreversible losses of nonferrous and precious metals with a waste iron cake as much as possible (the losses of nickel and cobalt were decreased by 11 times; those of copper, by 23 times; platinum, by $16 \%$; palladium, by $10 \%$; rhodium, by $9 \%$; gold, by 12\%); and the building and introduction of carbonate processing, which allowed the production of nickel cathodes to be increased. As a result of the measures taken to redistribute raw materials, the mattes of slag-cleaning furnaces, which contained $35-40 \% \mathrm{Fe}$, were moved to KGMK. This integration solution led to a significant synergy effect in Nornickel. One of the key factors of the economic efficiency of the matte-free technology was a decrease in the specific consumption of the main reagents (oxygen, air, sulfuric acid) and the energy resources used for the manufacture of nickel products. As a result, the transaction costs were decreased by $\sim 3.5$ mln dollars per year.
\end{abstract}

Keywords: Norilsk Nickel Harjavalta, converter matte, matte of slag-cleaning furnaces, hydrometallurgical processing, sulfate leaching, matte-free technology, nickel, copper, platinum, palladium, copper cake, iron cake, nickel cathodes

DOI: $10.1134 / \mathrm{S} 0036029519050069$

\section{INTRODUCTION}

In March 2007, Nornickel bought the nickel assets in Finland (enterprise Harjavalta) and Australia [1, 2]. ${ }^{1}$

When buying Harjavalta, Nornickel acquired the following advantages: an increase in the fraction on the market (including the production of nickel salts with a high added value) and market synergy. However, the main motif of the deal was a widening of the

\footnotetext{
${ }^{1}$ The following abbreviations are used in this work: company Nornickel stands for OAO GMK Norilsk Nickel (since 2016, PAO GMK Norilsk Nickel); enterprise Harjavalta, for enterprise OMG Harjavalta Nickel Oy; enterprise $\mathrm{NNH}$, enterprise Norilsk Nickel Harjavalta (since 2007, Finnish refining plant of Nornickel); ZF Nornickel, Arctic Branch of GMK Norilsk Nickel); GMOITs, Mining and Metallurgical Research Center of ZF (since January 2011, Center of Engineering Maintenance of Production); KGMK, OAO Kol'sk GMK of GMK Norilsk Nickel; and BOHA, Swedish metallurgical company Boliden Harjavalta Smelter.
}

raw materials base and access to new advanced hydrometallurgical technologies, mainly the sulfate technology of nickel refining. This technology is of particular interest for Nornickel because of a planned modification of analogous production in its $\mathrm{ZF}$ according to sulfate technology adapted for the Norilsk copper converter matte $[2,3]$.

\section{NICKEL REFINING IN HARJAVALTA/NNH}

Enterprise Harjavalta is located in the west of Finland at the territory of industrial megapark Harjavallan Suurteollisuuspuisto, which is the largest industrial park in the North Europe and is characterized by a well developed infrastructure and the presence of a combined production cluster. This enterprise uses the latest achievements of pyro- and hydrometallurgy and 
is one of the world leaders in the field of autogenous processes and the pressure hydrometallurgy of copper-nickel materials. Until 2000, it was a key production division in the composition of the scientific-production cluster of concern Outokumpu, which is known in the copper-nickel industry due to its advanced technologies and unique engineering solutions [4-7].

In 1995, a unique process of converter-free smelting of nickel concentrates, namely, direct Outotec nickel (DON) smelting process, was implanted for the first time in the nickel line of the Harjavalta plant. The final stage of this process is a two-flow nickel refining scheme with the production of commercial metallic nickel, cobalt compounds, and cathode copper [5, 7].

At present, enterprise NNH in the composition of Nornickel companies is one of the most diversified nickel-refining productions in the industry and its commercial products are as follows:

(a) cathode nickel, nickel briquettes, nickel powders, chemically pure nickel salts (sulfate, hydroxycarbonate, carbonate, hydroxide), and sulfate nickel solution;

(b) copper residue of leaching (copper cake), which contains copper and the entire spectrum of precious metals coming with initial raw materials $(\mathrm{Au}, \mathrm{Ag}, \mathrm{Pt}$, $\mathrm{Pd}, \mathrm{Rh}$, etc.);

(c) chemically pure cobalt sulfate;

(d) crystalline ammonium sulfate.

$\mathrm{NNH}$ is a single nickel refining enterprise in Finland and the largest world enterprise for the production of high-quality crystalline nickel sulfate. In the production of nickel, it is the third nickel-refining production in Europe and is only inferior to Russian KGMK and Norwegian Nikkelverk of company Xstrata. In the production of nickel, NNH occupies the seventh place in the world and passes ahead of well-known nickel refining enterprises INCO Thompson (Canada), Sherritt (Canada), Clydach (Great Britain), Sumitomo (Japan), and Murrin Murrin (Australia).

Enterprise NNH fully meets the ecological requirements of European Standard, has a high level of production safety, and uses the following most advanced world hydrometallurgical processes: atmospheric and pressure oxidation leaching, pressure refining in a nitrogen atmosphere, three types of liquid extraction (calcium, cobalt, nickel), pressure hydrogen reduction of nickel with the formation of nickel powders and briquettes, electric extraction of nickel, and the production of chemically pure nickel and cobalt salts for high-tech processes. High-purity ( $\geq 99 \%$ ) gaseous reagents, namely, commercial-purity oxygen and hydrogen, are used in pressure processes.

The research team of NNH consists of high-quality scientific staff of Harjavalta, which has experience of development and introduction of modern hydromet- allurgical processes in various divisions of concern Outokumpu.

As a result of the system of constant improvement of production crated earlier in concern Outokumpu, the following unique high-capacity last-generation equipment is used in NNH: large-volume autoclaves with a titanium lining of a body, chemical reactors with Oktop mixers, high-speed Superflow thickeners, Outotec extractors, continuous computer-assisted Larox filter presses, and Pannevis vacuum belt filters.

The technical level of almost all equipment is higher than well-known world analogs. The processes are fully automated and equipped with computer control systems. All production processes are characterized by a high degree of mechanization and automation.

The industrial experience and the technical and intellectual potential accumulated in NNH determined prospects for the improvement of nickel refining in ZF Nornickel. In addition, the technological solutions proposed in ZF laboratories, which were tested on local pilot GMOITs plants, were used in $\mathrm{NNH}$ because of the complex chemical composition of the supplied raw materials.

The technological break in creating combined sulfate schemes of processing copper-nickel converter matte is related to the use of technical oxygen in pressure processes, the production of large-volume autoclaves, and the application of liquid extraction of nickel and cobalt using the derivatives of phosphinic acid as extracting agents.

In 1998-2000, researchers at GMOITs Nornickel developed a combined sulfate technology to process a granulated high-copper converter matte $(\mathrm{Cu}: \mathrm{Ni} \sim 2: 1)$ $[8,9]$. This converter matte should be produced from the combined copper-nickel concentrates of the Talnakh and Norilsk concentrating mills of ZF Nornickel [10]. The technology was based on the scheme of combined hydrometallurgical processing of the matte from flash smelting furnaces (FSFs) and the matte of slagcleaning furnaces (SCFs) (Fig. 1). This scheme was introduced in enterprise Harjavalta in 1995 (development of Outokumpu) [4, 11]. A number of key solutions of the hydrometallurgical technology of Harjavalta, which is a component of the unique technological DON process, have no comparable commercial analogs in the world [7].

The main operations in the process flowsheet in GMOITs are as follows: water granulation ("quenching") of a molten converter matte; fragmentation of a granulated product; sulfate leaching of the converter matte by return $\mathrm{Ni}$ anolyte with the formation of a NiCo solution, a sulfide copper product, and a return iron cake; liquid extraction of cobalt using a Tsianeks-272 extracting agent; the production of electrolyte nickel and cobalt; the desulfurization of part of the return $\mathrm{Ni}$ anolyte by soda with the formation of a sodium sulfate-containing outflow; the evaporation of the outflow, the subsequent processing of crystalline sodium 


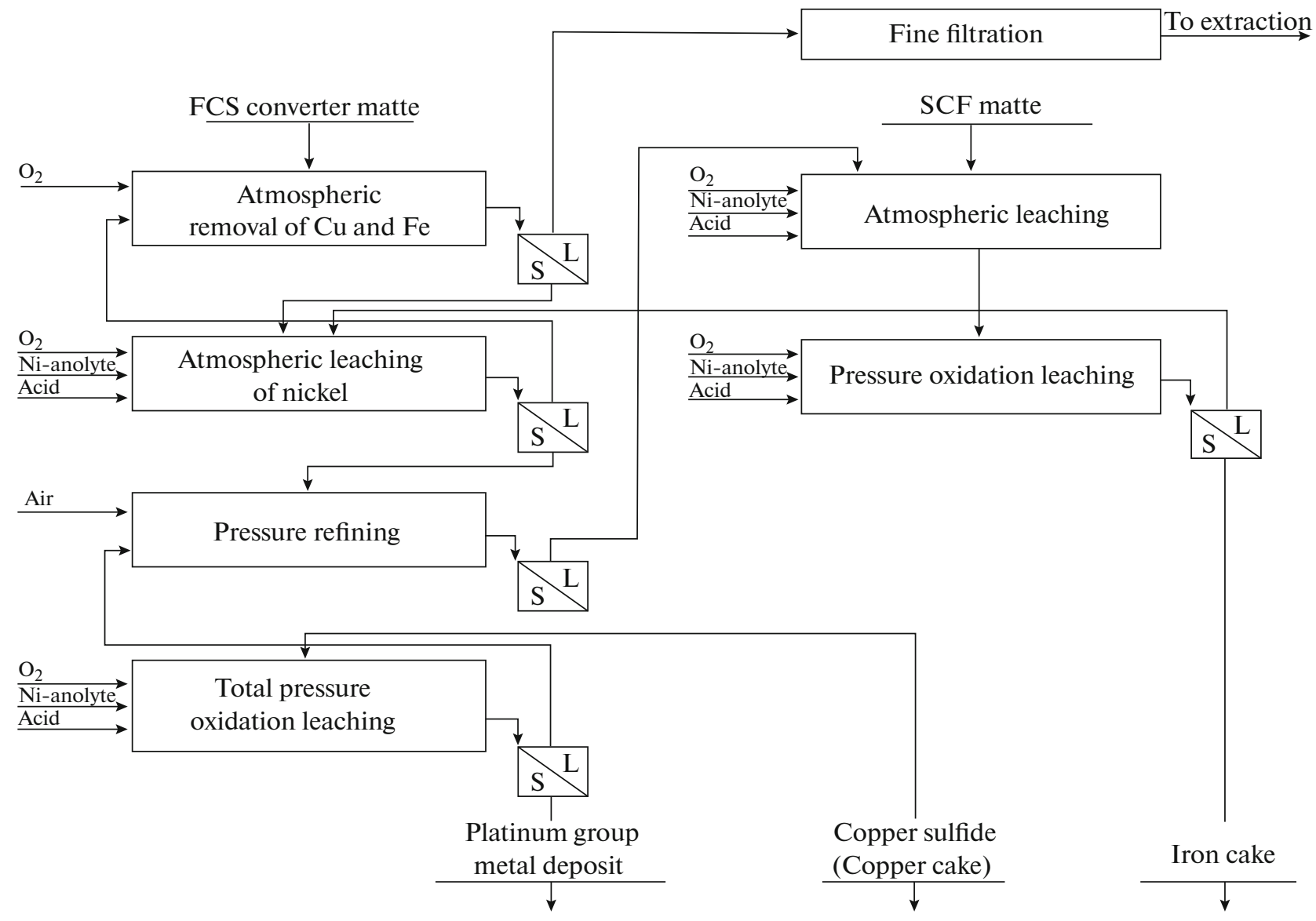

Fig. 1. Flowsheet for leaching the FCS converter matte and the SCF matte in the Harjavalta plant of company Outokumpu during the introduction of new nickel-refining production in 1995 [4].

sulfate in the FSFs of the Nadezhdinsk metallurgical plant (NMP) in the composition of a nickel concentrate charge, and the use of the condensate in hydrometallurgy (Fig. 2) [9].

When analyzing this technology, we found that the Outokumpu scheme does not meet the requirements of the project in the composition of the synthesized copper cake, the recovery of precious metals, and some other parameters. Complex high-copper raw materials and the problem of installation of new nickel-refining production into the operating metallurgical complex along with the requirements of achieving a higher level of ecological safety made it necessary to search for new thermal conductivity solutions to meet the formulated requirements with allowance for the specific conditions of Norilsk and the condition of the maximum use of the existing equipment and the industrial areas [3]. The technical and technological solutions found by engineers in GMOITs allowed the indices of processing converter matte to be radically improved as compared to the base Outokumpu technology [9, 12]. Figure 3 shows the flowsheet of leaching. It has the following radical differences from the base technology: separate removal of copper and iron from a nickel solution, the addition of a copper-containing MTs-1 solution to oxidizing pressure leaching to improve the oxidation kinetics of nickel sulfides, and the sequence of oxidizing pressure leaching and pressure refining. However, despite these differences, the technology developed in GMOITs for ZF genetically inherited a number of technological and apparatus solutions of the Harjavalta scheme.

Table 1 gives data on similar and different technical solutions in the nickel refining schemes of Harjavalta (Outokumpu) and ZF (GMOITs) and the key technological indices of both schemes. A comparison of these data demonstrates that the GMOITs technology developed for high-copper raw materials reaches higher recovery of nickel ( $\geq 99$ against $96-97 \%)$ and the platinum-group metals (PGMs; $\geq 99$ against $\sim 90 \%$ ) into a commercial product as compared to the Outokumpu technology. The high quality of the copper cake produced by the GMOITs technology (71$72 \% \mathrm{Cu}, 0.4-0.6 \% \mathrm{Ni}, 0.2-0.4 \% \mathrm{Fe}, 26-28 \% \mathrm{~S}$ ) allowed us to process it according to the scheme of direct synthesis of blister copper in a Vanyukov furnace bypassing the stage of conversion in PeirceSmith converters $[9,13]$. The GMOITs technology is 


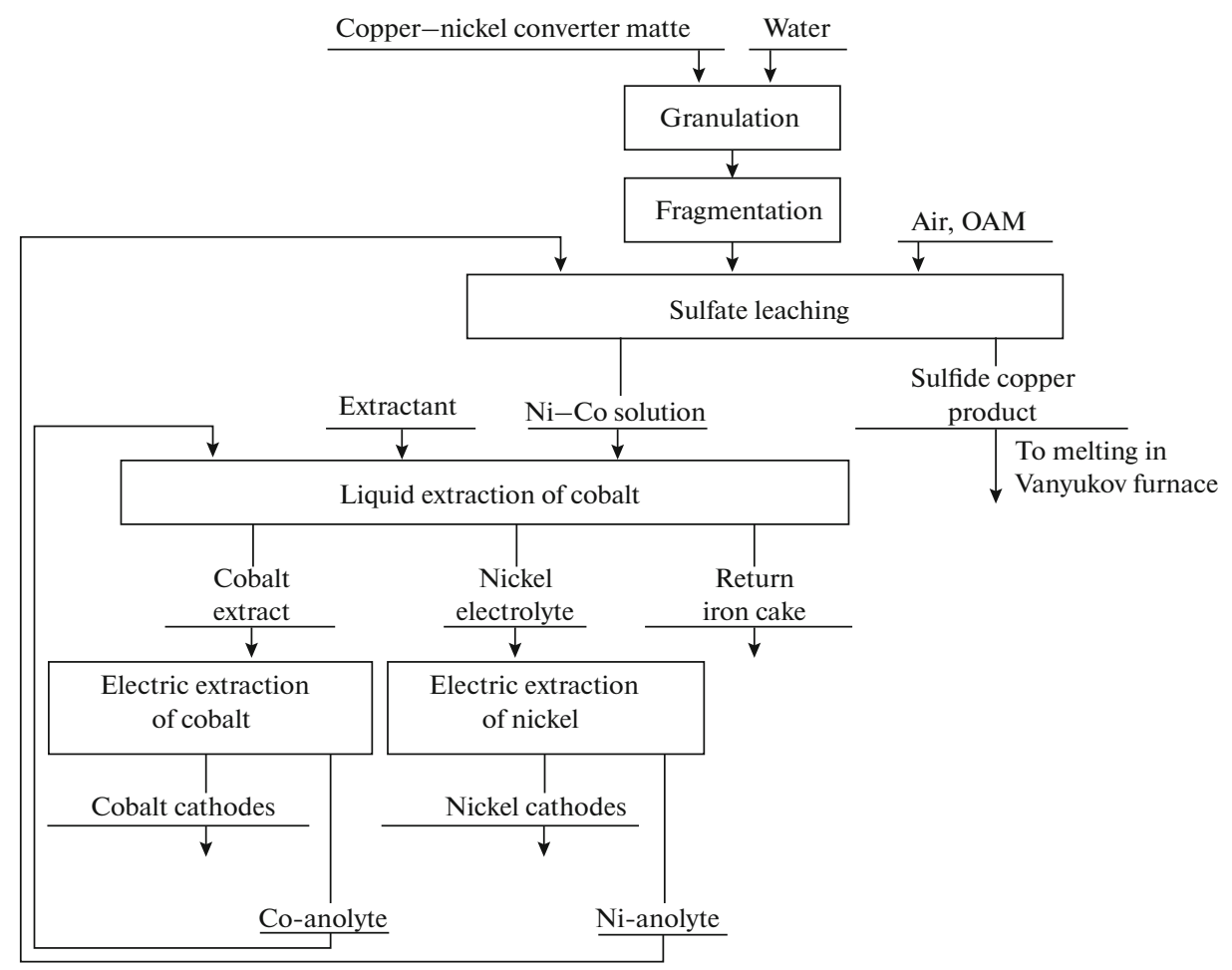

Fig. 2. Flowsheet for the combined processing of copper-nickel converter matte proposed by GMOITs for NMZ in 1998 [9].

also characterized by lower important component contents in the iron cake $(1.2-2 \% \mathrm{Ni})$ and the absence of copper and precious metal losses, which is caused by iron deposition conditions [12]. The advantages of the GMOITs technology are most pronounced when copper raw materials with a high PGM content are processed.

This technology was tested on local pilot GMOITs plants on semi-industrial and industrial (electric extraction of nickel) scales.

The developed scheme of sulfuric acid processing of copper-nickel converter matte uses a number of nonstandard technological solutions, and its technical-and-economic indices are substantially higher than the well-known foreign analogs. An important advantage of this technology is universality, i.e., the possibility of effective processing of both standard (selective) and high-copper (collective) converter mattes to be processed.

\section{TECHNOLOGICAL SOLUTIONS OF RESEARCHERS FROM NORILSK-ONE OF THE FACTORS IN SOLVING THE PROBLEMS OF RAW MATERIALS IN HARJAVALTA}

In 2008-2009, intracorporative technology transfer (ICTT) started in the production unit NNH-ZF: the technology developed by GNITs for processing the high-copper Norilsk converter matte was subjected to pilot tests on the operating facilities of NNH. The test results supported the efficiency of the technical solutions used for the technology developed in ZF and demonstrated its universality, i.e., the possibility of processing melted materials over a wide mass ratio $\mathrm{Cu}$ : Ni range.

The next step in ICTT was the activity of Russian experts in Nornickel for solving the most important production problems of NNH. This activity included the development of new technological processes and schemes in cooperation with NNH and the transfer of technical solutions and the results of Russian applied research works to $\mathrm{NNH}$ experts for experimental tests. As a result of the use of high-copper raw materials in $\mathrm{NNH}$, the experience of Norilsk researchers accumulated during their work with high-copper and copper converter mattes was used.

In 2009-2010, the integration of the raw materials of NNH with new foreign nickel assets of Nornickel (Republic of South Africa, Botswana) led significant changes in the chemical-mineralogical composition of the concentrates supplied to BOHA and, correspondingly, the composition of the raw materials in the charge of NNH.

The global financial crisis in 2008 and the sharp decrease in the world metal prices resulted in the conservation of all Australian nickel assets of Nornickel, which stopped the supply of nickel-rich raw materials (Black Swan concentrate, Cawse carbonates) to BOHA and NNH. In 2010, the copper-nickel 


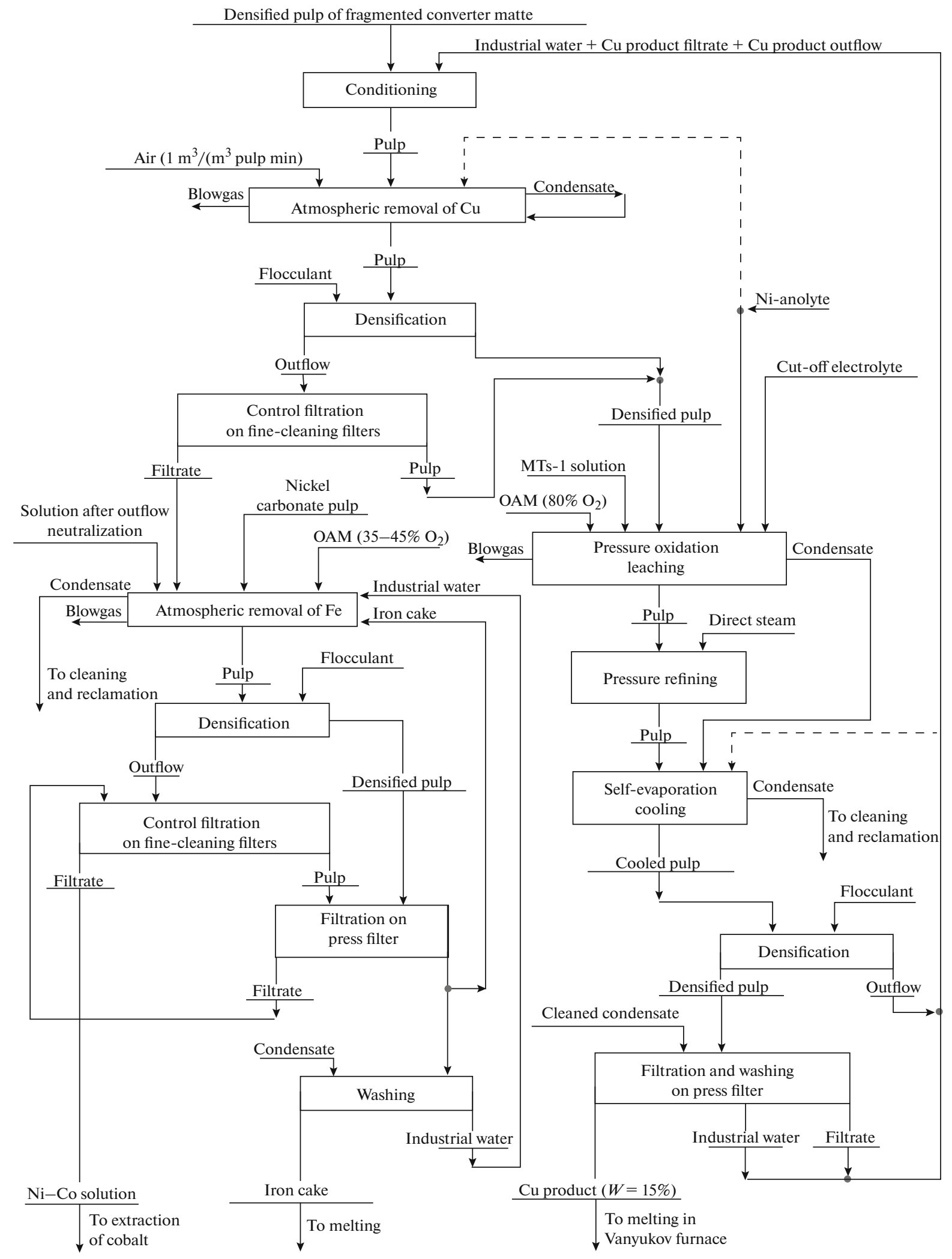

Fig. 3. Flowsheet for the sulfate leaching of copper-nickel converter matte developed by GMOITs in $1998-2000$ for ZF Nornickel (OAM is an oxygen-air mixture, $W$ is the humidity). 
Table 1. Similar and different elements in the nickel-refining technologies developed in Outokumpu [4] and GMOITs of ZF Nornickel [9]

\begin{tabular}{|c|c|c|c|}
\hline \multirow{2}{*}{ No. } & \multirow{2}{*}{$\begin{array}{l}\text { Characteristic sign } \\
\text { of technology }\end{array}$} & \multicolumn{2}{|c|}{ Company-designer of technology } \\
\hline & & “Outokumpu” & GMOITs of ZF Nornickel \\
\hline \multicolumn{4}{|c|}{ I. Similar technological elements } \\
\hline 1 & Initial raw materials & Granulated melted materials & Granulated melted materials \\
\hline 2 & Type of technology & Hydrometallurgical, sulfate & Hydrometallurgical, sulfate \\
\hline 3 & $\begin{array}{l}\text { Concept of process } \\
\text { flowsheet }\end{array}$ & $\begin{array}{l}\text { Water granulation-fragmentation-leach- } \\
\text { ing-liquid extraction-electric extraction } \\
\text { of nickel-cobalt production }\end{array}$ & $\begin{array}{l}\text { Water granulation-fragmentation-leach- } \\
\text { ing-liquid extraction-electric extraction } \\
\text { of nickel-cobalt production }\end{array}$ \\
\hline 4 & Type of leaching & $\begin{array}{l}\text { Atmospheric pressure oxidation } \\
\left(\mathrm{O}_{2} \text { is oxidizer }\right) \text {, pressure refining } \\
\text { in nitrogen atmosphere }\end{array}$ & $\begin{array}{l}\text { Atmospheric pressure oxidation } \\
\left(\mathrm{O}_{2} \text { is oxidizer }\right) \text {, pressure refining } \\
\text { in nitrogen atmosphere }\end{array}$ \\
\hline 5 & $\begin{array}{l}\text { Fine cleaning of } \mathrm{Ni}-\mathrm{Co} \\
\text { solution from iron and } \\
\text { copper }\end{array}$ & $\begin{array}{l}\text { Atmospheric, in oxidizing atmosphere } \\
\left(\mathrm{O}_{2} \text { is oxidizer }\right)\end{array}$ & $\begin{array}{l}\text { Atmospheric, in oxidizing atmosphere } \\
\left(\mathrm{O}_{2} \text { is oxidizer }\right)\end{array}$ \\
\hline 6 & Type of leaching agent & $\begin{array}{l}\text { Leaching of the semiproducts } \\
\text { of technology using the return Ni anolyte } \\
\text { formed in electric extraction of nickel }\end{array}$ & $\begin{array}{l}\text { Leaching of the semiproducts } \\
\text { of technology using the return } \mathrm{Ni} \text { anolyte } \\
\text { formed in electric extraction of nickel }\end{array}$ \\
\hline 7 & $\begin{array}{l}\text { Type of organic extractant } \\
\text { for separation of cobalt } \\
\text { from nickel }\end{array}$ & $\begin{array}{l}\text { Separation of nickel and cobalt in sulfate } \\
\text { solution using di( } 2,4,4 \text {-trimethylpen- } \\
\text { tyl)phosphinic acid (Tsianeks-272) as } \\
\text { organic extractant }\end{array}$ & $\begin{array}{l}\text { Separation of nickel and cobalt in sulfate } \\
\text { solution using di(2,4,4-trimethylpen- } \\
\text { tyl)phosphinic acid (Tsianeks-272) as } \\
\text { organic extractant }\end{array}$ \\
\hline 8 & \begin{tabular}{|l|}
$\begin{array}{l}\text { Method of processing } \\
\text { of sulfide copper products } \\
\text { (copper cake) }\end{array}$ \\
\end{tabular} & $\begin{array}{l}\text { Melting in autogenous furnace } \\
\text { (in FSF in the copper line of Harjavalta) }\end{array}$ & $\begin{array}{l}\text { Melting in autogenous furnace } \\
\text { (in Vanyukov furnaces in NMP) }\end{array}$ \\
\hline 9 & $\begin{array}{l}\text { Method of processing } \\
\text { of return iron cake }\end{array}$ & $\begin{array}{l}\text { Melting in autogenous furnace } \\
\text { (in FSF in the nickel line of Harjavalta } \\
\text { in the composition of nickel concentrate } \\
\text { charge) }\end{array}$ & $\begin{array}{l}\text { Melting in autogenous furnace } \\
\text { (in FSF in NMP in the composition } \\
\text { of nickel concentrate charge }\end{array}$ \\
\hline 10 & $\begin{array}{l}\text { Product used to remove } \\
\text { excess sulfur }\end{array}$ & Sodium sulfate (partly) & Sodium sulfate (completely) \\
\hline 11 & Equipment for leaching & $\begin{array}{l}\text { Multisectional high-power horizontal } \\
\text { autoclaves, vertical reactors with mixers, } \\
\text { automatic Larox press filters, Superflow } \\
\text { thickeners }\end{array}$ & $\begin{array}{l}\text { Multisectional high-power horizontal } \\
\text { autoclaves, vertical reactors with mixers, } \\
\text { automatic Larox press filters, Superflow } \\
\text { thickeners }\end{array}$ \\
\hline \multicolumn{4}{|c|}{ II. Distinguishing technological elements } \\
\hline 1 & $\begin{array}{l}\text { Composition of initial } \\
\text { raw materials }\end{array}$ & $\begin{array}{l}\text { Technology is not universal. It was devel- } \\
\text { oped for low-copper raw materials with a } \\
\text { very low PGM content. Products: (i) high- } \\
\text { nickel converter mattes ( } 60-65 \% \mathrm{Ni} \text {, } \\
5-7 \% \mathrm{Fe}, 20-22 \% \mathrm{~S}) \text { with a low content } \\
\text { of copper }(4-5 \% \mathrm{Cu}) \text { and PGM } \\
(\Sigma \mathrm{PGM}=1-5 \mathrm{ppm}) \text {, (ii) high-metal SCF } \\
\text { matte with a high iron content and a very } \\
\text { low PGM content }(\sim 50 \% \mathrm{Ni}, 5 \% \mathrm{Cu}, \\
30-40 \% \mathrm{Fe}, 6-7 \% \mathrm{~S}, \Sigma \mathrm{PGM}<0.5 \mathrm{ppm})\end{array}$ & $\begin{array}{l}\text { Technology is universal and intended to } \\
\text { process high-copper raw materials with a } \\
\text { high PGM content. Products: (i) high- } \\
\text { copper converter matte ( } 24 \% \mathrm{Ni}, 48 \% \mathrm{Cu} \text {, } \\
3 \% \mathrm{Fe}, 22 \% \mathrm{~S}, \Sigma \mathrm{PGM} \sim 200 \mathrm{ppm}), \\
\text { (ii) copper-nickel converter matte }(52- \\
55 \% \mathrm{Ni}, 18-22 \% \mathrm{Cu}, 2-3 \% \mathrm{Fe}, 21-23 \% \mathrm{~S}) \text {, } \\
\text { (iii) copper concentrate from flotation } \\
\text { separation of slowly cooled converter } \\
\text { matte }(5 \% \mathrm{Ni}, 68 \% \mathrm{Cu}, 3 \% \mathrm{Fe}, 21 \% \mathrm{~S}, \\
\Sigma \mathrm{PGM} \sim 70 \mathrm{ppm})\end{array}$ \\
\hline
\end{tabular}


Table 1. (Contd.)

\begin{tabular}{|c|c|c|c|}
\hline \multirow{2}{*}{ No. } & \multirow{2}{*}{$\begin{array}{l}\text { Characteristic sign } \\
\text { of technology }\end{array}$} & \multicolumn{2}{|c|}{ Company-designer of technology } \\
\hline & & "Outokumpu" & GMOITs of ZF Nornickel \\
\hline 2 & Flowsheet of leaching & $\begin{array}{l}\text { Two-flow scheme of combined leaching } \\
\text { of FSF converter matte and metallized } \\
\text { SCF matte in individual chains with } \\
\text { integration of technological middlings }\end{array}$ & $\begin{array}{l}\text { One-flow scheme of leaching converter } \\
\text { matte }\end{array}$ \\
\hline 3 & $\begin{array}{l}\text { Technology of fine } \\
\text { cleaning of } \mathrm{Ni}-\mathrm{Co} \\
\text { solution from copper } \\
\text { and iron }\end{array}$ & $\begin{array}{l}\text { Combined atmospheric cleaning from } \\
\text { copper and iron to a residual concentration } \\
\text { of }<1 \mathrm{mg} / \mathrm{dm}^{3} \text { each. Caustic soda is used as } \\
\text { a neutralizer (if necessary) }\end{array}$ & $\begin{array}{l}\text { Separate atmospheric cleaning from cop- } \\
\text { per and iron at the head of technological } \\
\text { leaching scheme. Nickel carbonate pulp is } \\
\text { used as a neutralizer for the removal of } \\
\text { iron. Primary iron cake is subjected to acid } \\
\text { repulping to decrease the nckel content to } \\
\leq 1.5 \%\end{array}$ \\
\hline 4 & $\begin{array}{l}\text { Iron deposition } \\
\text { technology }\end{array}$ & $\begin{array}{l}\text { The first stage of iron deposition is com- } \\
\text { bined with pressure leaching of SCF matte } \\
\text { and is performed in pulp }\end{array}$ & $\begin{array}{l}\text { Iron is deposited under atmospheric con- } \\
\text { ditions in one stage from the solution pre- } \\
\text { liminarily cleaned from solid particles }\end{array}$ \\
\hline 5 & $\begin{array}{l}\text { Number of stages } \\
\text { of leaching of nickel } \\
\text { in converter matte line }\end{array}$ & $\begin{array}{l}\text { Four stages: atmospheric cleaning from } \\
\text { copper and iron, atmospheric leaching, } \\
\text { pressure refining, pressure oxidation } \\
\text { leaching }\end{array}$ & $\begin{array}{l}\text { Three stages: atmospheric cleaning from } \\
\text { copper, pressure oxidation leaching, pres- } \\
\text { sure refining }\end{array}$ \\
\hline 6 & $\begin{array}{l}\text { Sequence of the stages } \\
\text { of pressure leaching } \\
\text { of nickel }\end{array}$ & $\begin{array}{l}\text { Pressure refining-pressure oxidation } \\
\text { leaching }\end{array}$ & $\begin{array}{l}\text { Pressure oxidation leaching-pressure } \\
\text { refining }\end{array}$ \\
\hline 7 & Nickel products & $\begin{array}{l}\text { Two types of nickel products: (i) nickel } \\
\text { cathodes produced by electric extraction of } \\
\text { nickel from sulfate solutions, (ii) nickel } \\
\text { powders and briquettes produced by } \\
\text { hydrogen reduction of nickel in autoclaves } \\
\text { from ammonia-sulfate solutions }\end{array}$ & $\begin{array}{l}\text { Nickel cathodes produced by electric } \\
\text { extraction of nickel from sulfate solutions }\end{array}$ \\
\hline 8 & Cobalt products & $\begin{array}{l}\text { Chemically pure salts and a wide range of } \\
\text { metallic powders }\end{array}$ & $\begin{array}{l}\text { Cobalt cathodes produced by electric } \\
\text { extraction of cobalt from sulfate solutions }\end{array}$ \\
\hline 9 & $\begin{array}{l}\text { Main channels } \\
\text { of removal of oxidized sul- } \\
\text { fur from process flowsheet } \\
\text { and the methods of recla- } \\
\text { mation of formed sulfur- } \\
\text { containing products }\end{array}$ & $\begin{array}{l}\text { Two main channels: (i) fixation of sulfur by } \\
\text { sodium sulfate, formation of } \mathrm{Na}_{2} \mathrm{SO}_{4} \text {-con- } \\
\text { taining outflow, dumping of a certain } \\
\text { amount to river; (ii) fixation of sulfur by } \\
\text { ammonium sulfate during hydrogen } \\
\text { reduction of nickel; evaporation of solu- } \\
\text { tion, formation of commercial product and } \\
\text { its sale }\end{array}$ & $\begin{array}{l}\text { Channels: (i) desulfurization of part of the } \\
\text { return Ni anolyte by soda solution at the } \\
\text { stage of carbonate processing in nickel } \\
\text { electroextraction plant; (ii) formation of a } \\
\mathrm{Na}_{2} \mathrm{SO}_{4} \text {-containing concentrated } \\
\text { outflow, evaporation of outflow, formation } \\
\text { of crystalline } \mathrm{Na}_{2} \mathrm{SO}_{4} \text {, and its melting in } \\
\text { FSF in the composition of nickel concen- } \\
\text { trate charge }\end{array}$ \\
\hline \multicolumn{4}{|c|}{ III. Main technological indices } \\
\hline 1 & $\begin{array}{l}\text { Chemical composition of } \\
\text { sulfide copper product } \\
\text { (copper cake) }\end{array}$ & $\begin{array}{l}\mathrm{Cu} 33-35 \% \text {; Ni } 5-6 \% \text {; Fe } 11-15 \% \text {; } \\
\text { S } 14-15 \%\end{array}$ & $\begin{array}{l}\mathrm{Cu} 71-72 \% \text {; Ni } 0.4-0.6 \% \\
\mathrm{Fe} 0.2-0.4 \% \text {; S 26-28\% }\end{array}$ \\
\hline 2 & $\begin{array}{l}\text { Chemical composition of } \\
\text { iron cake }\end{array}$ & $\begin{array}{l}\text { Ni 2-6\%; Cu 2-6\%; Fe 54-59\%; } \\
\text { S 3-5\%; } \text { PGM 7-22 ppm; } \\
\text { Au 1.2-2.5 ppm; Ag 20-40 ppm }\end{array}$ & $\begin{array}{l}\text { 1.2-2\% N; Cu } \sim 0 ; \mathrm{Fe} 54-56 \% \\
\mathrm{~S} 5-8 \% ; \Sigma \mathrm{PGM} \sim 0 \mathrm{ppm} ; \mathrm{Au} \sim 0 \mathrm{ppm} \\
\mathrm{Ag} \sim 0 \mathrm{ppm}\end{array}$ \\
\hline
\end{tabular}


Table 1. (Contd.)

\begin{tabular}{|c|c|c|c|}
\hline \multirow{2}{*}{ No. } & \multirow{2}{*}{$\begin{array}{l}\text { Characteristic sign } \\
\text { of technology }\end{array}$} & \multicolumn{2}{|c|}{ Company-designer of technology } \\
\hline & & "Outokumpu" & GMOITs of ZF Nornickel \\
\hline 3 & $\begin{array}{l}\text { Nickel recovery to com- } \\
\text { mercial product }\end{array}$ & $96-97 \%$ & $\geq 99 \%$ \\
\hline 4 & $\begin{array}{l}\text { Precious metal recovery } \\
\text { to sulfide copper product } \\
\text { (copper cake) }\end{array}$ & $\sim 90 \%$ & $\geq 99 \%$ \\
\hline 5 & $\begin{array}{l}\text { Method of pLrocessing } \\
\text { of sulfide copper product } \\
\text { (copper cake) }\end{array}$ & $\begin{array}{l}\text { Copper matte smelting in the composition } \\
\text { of ore copper concentrate charge }\end{array}$ & $\begin{array}{l}\text { Direct (converter-free) blister copper } \\
\text { smelting in Vanyukov furnaces }\end{array}$ \\
\hline
\end{tabular}

cuprous concentrate from African enterprise Nkomati (Republic of South Africa) was supplied to BOHA for the first time, and the supply of the cuprous metallurgical middings (FSF converter matte, SCF matte) from the Brazil Fortaleza plant to NNH increased. The change in the structure and the composition of the raw materials caused a substantial increase in the nonferrous and precious metal losses with waste ferrous cake, increased the operating expenses, and broke the water-acid balance in NNH. Therefore, its process flowsheet had to be radically changed.

As follows from the estimation of experts from Nornickel, the extraction of nickel from the mattes of SCF in Fortaleza and BOHA in the matte line of the NNH plant was only 92-94\%. Significant amounts of copper, cobalt, and almost all precious metals involved in the mattes of SCF were lost with a waste ferrous cake. As a result of losses in the matte line, the extraction of PGM $(\mathrm{Pt}+\mathrm{Pd})$ in $\mathrm{NNH}$ was only $72-77 \%$.

When using cuprous raw materials, NNH encountered another problem, namely, the limitation of processing SCF matte containing up to $20 \% \mathrm{Cu}$. This limitation was caused by the following fundamental specific feature of the NNH technology: the amount of copper coming from the matte line in the composition of a solution should be balanced with the amount of converter matte processed in the converter matte line. If the amount of converter matte was too low, copper could penetrate into the end nickel and cobalt products of the NNH plant.

When the copper content increased, the stability potential of the designed NNH technology, which was intended for processing the high-nickel Australian and Finnish raw materials, turned out to be too small to retain the planned capacity of nickel production in $\mathrm{NNH}$ at a simultaneous decrease in the costs and losses of important components in the matte line of NNH.

An analysis of the converter matte line in $\mathrm{NNH}$ and the data of investigations performed in GMOITs in 1998-2004 point to significant internal reserves of the process flowsheet. In particular, when cuprous converter mattes $(17-20 \% \mathrm{Cu})$ are processed, the recovery nickel and PGM in the converter matte line of NNH exceeded 98\%. When cuprous raw materials $(\geq 50 \% \mathrm{Cu})$ are processed according to the GMOITs technology (which is close to the converter matte line of $\mathrm{NNH}$ ), a high quality of the cuprous cake $(72-73 \%$ $\mathrm{Cu},<0.5 \% \mathrm{Ni}, 0.3 \% \mathrm{Fe}$ ) is achieved along with the specified purity of the nickel-cobalt products. $\geq 99 \%$ copper and PGM are extracted into the cuprous cake under proper conditions. An important advantage of the GMOITs technology is its universality, and the highest indices are reached when high-copper raw materials are processed.

Therefore, the problem of radical improvement of the NNH technology was solved using the following stages: (1) stop and subsequent modification of the matte line and (2) production integration of the $\mathrm{NNH}$ technology and the KGMK technologies.

The measures taken to redistribute raw materials in 2011 the SCF mattes produced by BOHA and Fortaleza were removed from the nickel-refining production in NNH. These mattes, which contained 35-40\% $\mathrm{Fe}$, were moved to converting in KGMK. Instead of ferrous mattes, the modified matte line of $\mathrm{NNH}$ was loaded nickel-free raw materials, i.e., the converter mattes of BOHA, Fortaleza, and BHP Billiton (BHPB). A significant synergy effect was reached in Nornickel owing to this integration solution.

Simultaneously with the processes of raw material and production consolidation of $\mathrm{NNH}$ with other divisions of Nornickel, "intellectual integration" based on ICTT took place. This type of integration is the main form of innovations and consists in mutual exchange of technologies and know-how between Nornickel enterprises.

The Nornickel metallurgical works (at present, ZF Nornickel), is in cooperation with Outokumpu in various fields of scientific-technical development of the mining and metallurgy complex for more than 40 years [14]. New prospects for interaction in scientific-tech- 


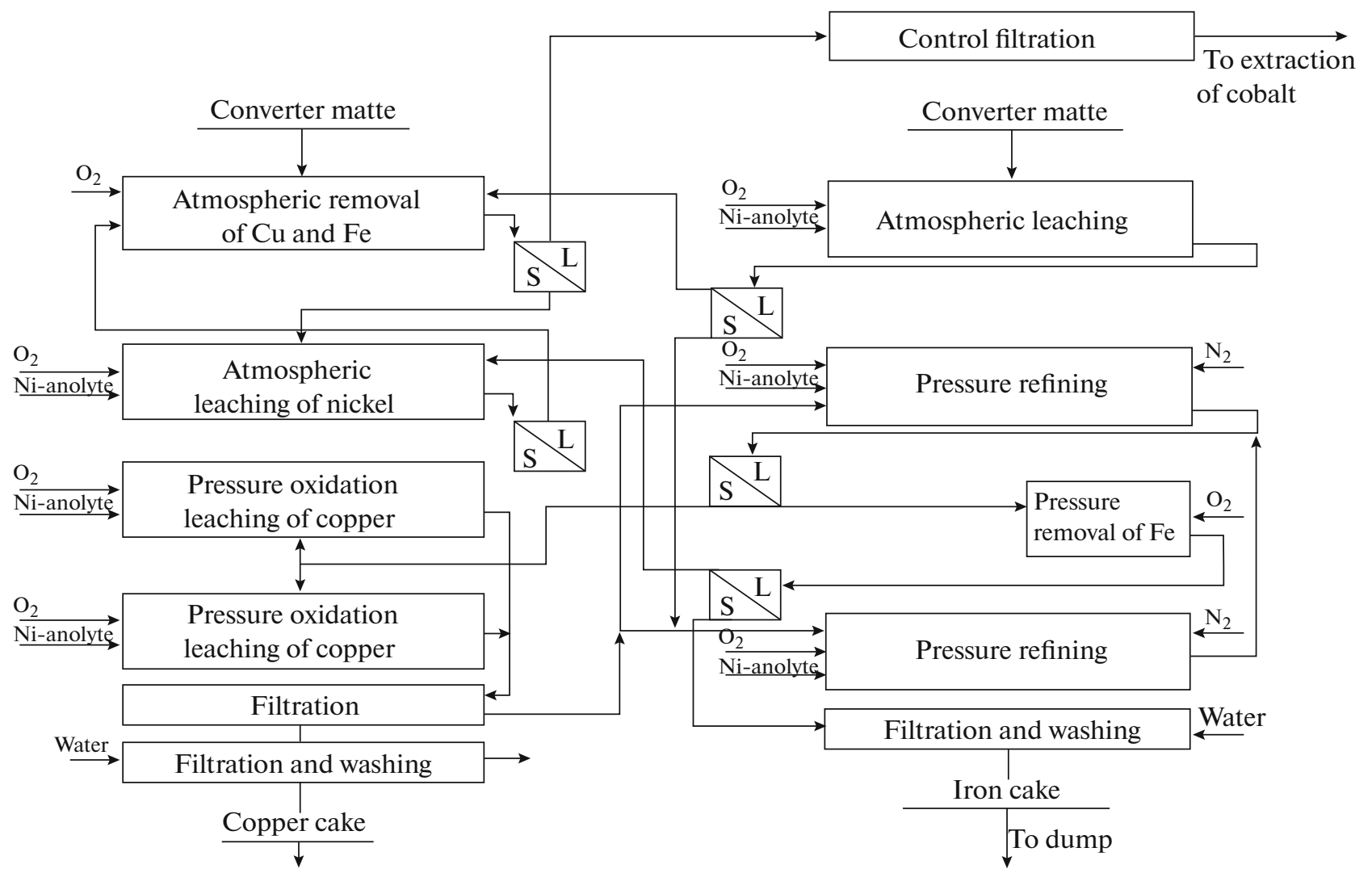

Fig. 4. Leaching flowsheet in NNH after the first stage of modification (first and second phases of the matte-free flowsheet).

nical and production spheres appeared in Nornickel due to the purchase of the Harjavalta plant.

The NNH enterprise becomes both an effective user of novel innovative technologies and the center of their commercial implementation, which is an important advantage of ICTT. In 2010-2012, the Russian researchers of the company proposed more than 20 innovative scientific-technical solutions in cooperation with researchers from NNH to accomplish ICTT. The main number of the technical solutions was implemented and gave rise to a significant economic effect for NNH and Nornickel.

The high technological sensitivity of NNH to the solutions proposed by Russian engineers is caused by the fact that all these solutions are genetically related to the basic technology of Harjavalta and help it to adapt to new conditions. Note the largest projects implemented in NNH and based on Russian technical proposals [15-17]:

(i) In 2011, the first stage of matte-free technology was performed with simultaneous modification of the matte line for processing converter matte (Fig. 4). Along with a decrease in the losses of nonferrous and precious metals in NNH and Nornickel, provided an increase in the capacity of leaching of converter matte in NNH by $25-30 \%$ and increased the output of commercial products. (ii) A jarosite technology of iron deposition from a nickel solution was introduced at the end of 2011 and allowed the losses of nonferrous and precious metals with waste ferrous cake to be minimized.

(iii) The implementation of the final (second) stage of modification of the matte-free technology in July 2012 allowed a cuprous cake with an improved composition to be produced (Fig. 5). During the stable operation of $\mathrm{NNH}$ on raw materials of a design composition $(5-7 \% \mathrm{Fe})$, we produced a sulfide copper cake containing $57-62 \% \mathrm{Cu}$. The copper cake of the improved composition contains $22-25 \%$ sulfide sulfur, $<3 \% \mathrm{Ni}$, and $8-11 \% \mathrm{Fe}$. The arsenic content in the cake was decreased from $1.5-2$ to $0.15-0.3 \%$.

(iv) The implementation of a "carbonate" process in August 2012 led to an increase in the output to $\sim 19$ ths $t$ nickel cathodes per year. These cathodes are most needed and profitable nickel metal products of NNH.

As a result of the implementation of innovative solutions of Russian and Finnish researchers in 20112012, the recovery of nonferrous and precious metals was increased. According to data from NNH, the recovery in 2012 was $(\%) 98.7 \mathrm{Ni}, 99.5 \mathrm{Cu}, 99.6 \mathrm{Pt}$, and 99.6 Pd.

As compared to the base technology, the redistribution of SCF mattes moved to processing in KGMK 


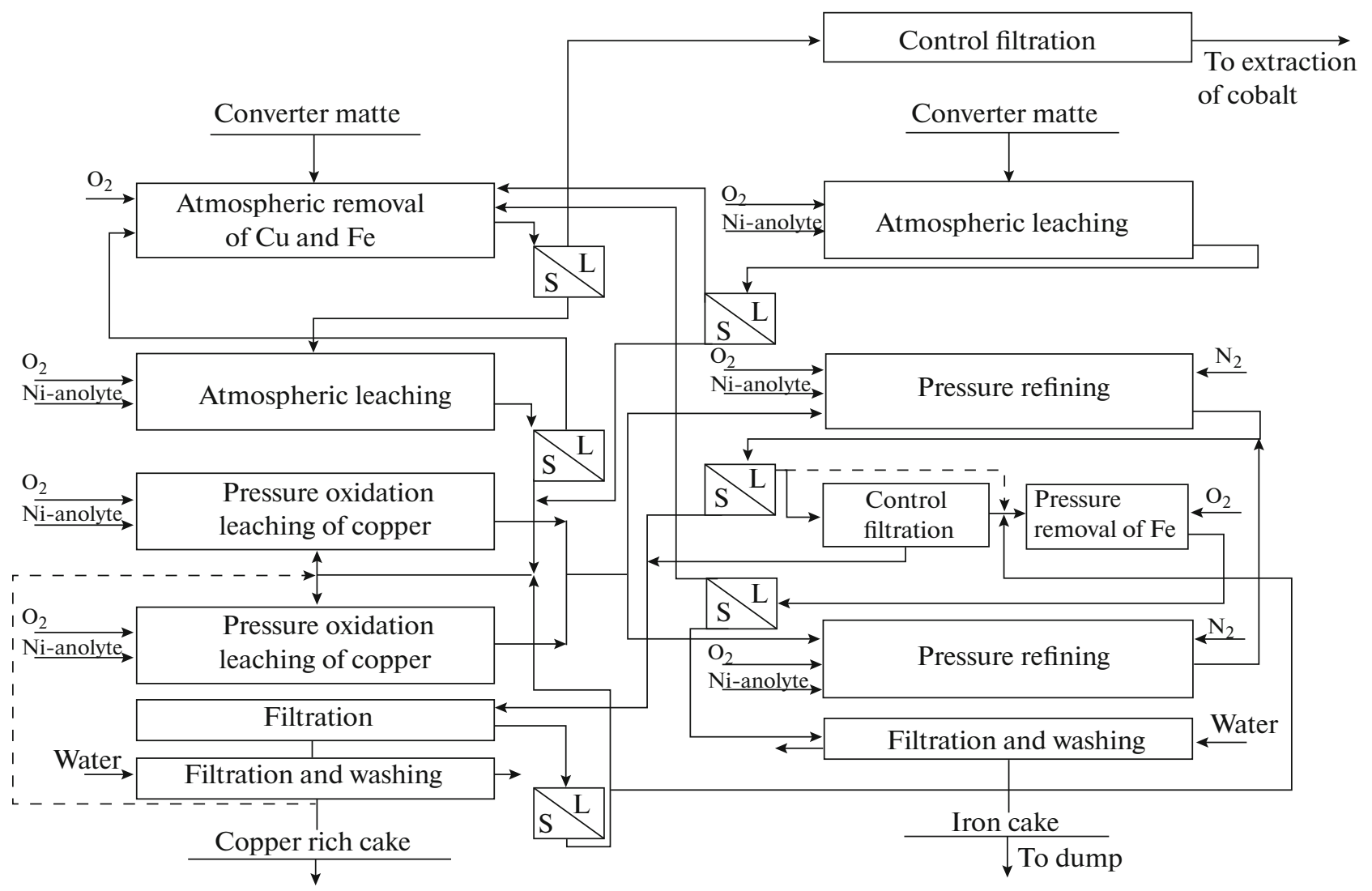

Fig. 5. Leaching flowsheet in NNH after the second stage of modification (third and fourth phases of the matte-free flowsheet).

significantly decreased the irreversible metal losses with a waste ferrous cake: the nickel and cobalt losses were decreased by 11 times; the copper losses, by 23 times; the platinum losses, by 16 abs \%; palladium, by 10 abs \%; rhodium, by 9 abs \%; and gold, by 12 abs $\%$.

One of the key factors of the economic efficiency of the matte-free technology was a decrease in the specific consumption of the main reagents (oxygen, air, sulfuric acid) and the energy resources for the manufacture of nickel products. As a result, the transaction costs in NNH were decreased by $\sim 3.5$ mln dollars per year.

Figure 6 shows the total scheme of processing in $\mathrm{NNH}$ after the modification performed for the mattefree technology.

In 2014, the third stage of modification of the $\mathrm{NNH}$ scheme of leaching using elements from the technology developed by GMOITs ZF was accomplished. A technology, which implies separate processing of converter mattes with different iron contents, was implemented. At this stage, the matte line and the jarosite scheme of iron deposition were used to develop a process of atmospheric leaching of highiron products. In this process, the SCF mattes are returned to processing in $\mathrm{NNH}$ without increasing the losses of nonferrous and precious metals as compared to the reached level. This scheme led to a decrease in the iron content in the copper cake to $\leq 6-7 \%$ and to an increase in the copper content in it to $60-65 \%$.

In 2014-2015, an innovative project for the production of chemically pure crystalline cobalt sulfate, which is based on liquid extraction and solidification, was implemented in NNH. ${ }^{2}$ This project was created and performed on the initiative of TU DOUP using a technology developed by the Russian and Finnish researchers of Nornickel. ${ }^{3}$

In 2016-2018, growing amounts of the slowly cooled copper-nickel converter matte of KGMK and the nickel concentrate produced from it by flotation were supplied to NNH for processing. The nickel concentrate had the following composition (\%): 68-69 Ni, $4-5 \mathrm{Cu}, 3-4 \mathrm{Fe}$, and $22-23 \mathrm{~S}$. The results of testing supported the efficiency of the improved NNH technology developed by researchers from $\mathrm{ZF}$ and $\mathrm{NNH}$ and demonstrated its universality, i.e., the possibility

\footnotetext{
${ }^{2}$ The field of application of the cobalt sulfate produced in NNH is wide: an electrolyte component for galvanic coating of other metals by cobalt; pigment for coloration of glass and ceramic; a unique mineral microfertilizer and feed microaddition in agriculture; pigment in the glass and ceramic industry; for medical and pharmaceutical purposes; drier of lithography ink, lacquer, dye, and linoleum; catalyst; and analytical reactive.

3 TU DOUP is Technical Control of the Department of Operation Administration of Nornickel.
} 


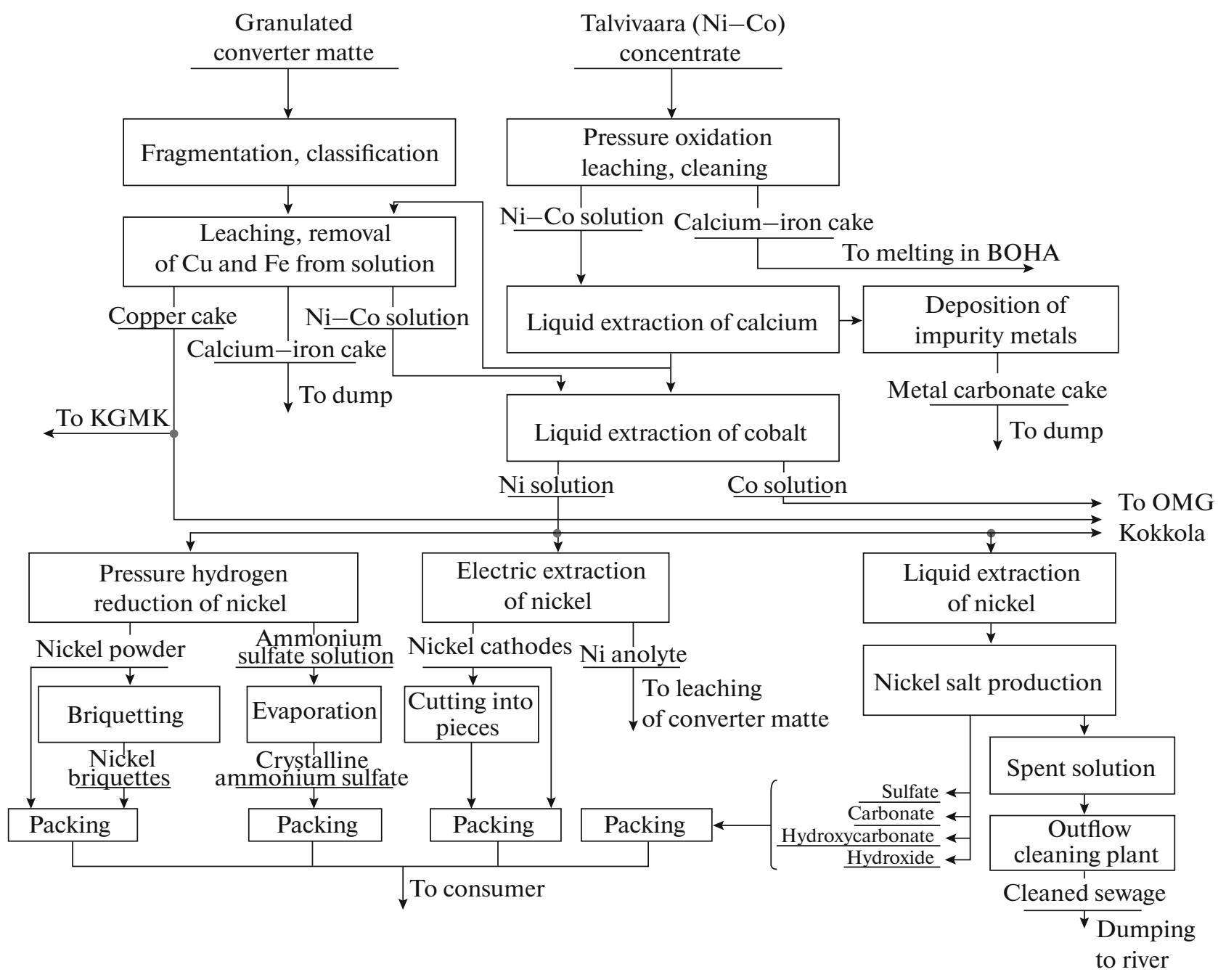

Fig. 6. Process flowsheet based on the matte-free technology in NNH (2013).

of efficient application for processing of both rapidly cooled (granulated) and slowly cooled melted materials over a wide range of $\mathrm{Cu}$ : $\mathrm{Ni}$ mass ratios.

It is important that, in contrast to the processing of high-copper raw materials, the hydrometallurgical processing of the selective converter mattes and the nickel concentrate produced by the separation of the copper-nickel converter matte has a number of specific features, which are mainly related to copper deficiency in pressure refining. It is necessary to introduce additional copper in the form of a solution or a sulfide copper-containing product into the preceding operation of pressure oxidation leaching. For example, part of the technological product (copper cake) should be returned to the head of pressure oxidation leaching [12]. This technique was adjusted in $\mathrm{NNH}$ in the period of industrial tests of the nickel concentrate from ZF (2008-2009) and was commercially implemented after the second stage of the matte-free technology.
The fast development of engineering and the growing competition on the metal market generate new market expectations and growing requirements for the quality and forms of the manufacture of metal products. Along with a constant change in the structure and composition of supplied raw materials, these features open up fresh opportunities for improving the technology of the nickel-refining production in NNH.

The leading technical experts and researches from $\mathrm{NNH}$, the head office, and ZF Nornickel are involved in the creation and implementation of all main projects in NNH. Along with the solutions of the researchers from NNH, the ideas, the experience, and the scientific and designing solutions of Norilsk engineers and designers are used in these projects.

\section{CONCLUSIONS}

(1) The purchase of Harjavalta by Nornickel followed by the formation of NNH provided intellectual 
integration based on ICTT, i.e., mutual exchange of technologies and know-how between Nornickel enterprises. Nornickel gained an access to new advanced hydrometallurgical technologies, mainly the sulfate technology of nickel refining.

(2) An important advantage of ICTT is the fact that $\mathrm{NNH}$ enterprise becomes both an effective user of novel innovative technologies and the center of their commercial implementation.

(3) In 2010-2012, the Russian engineers of Nornickel in cooperation with the engineers from $\mathrm{NNH}$ in terms of ICTT proposed more than 20 innovative research and technical solutions.

(4) As a result of the implementation of the innovative solutions, the recovery of nonferrous and precious metals in the nickel-refining production of NNH was significantly increased (\%): the recovery of nickel was increased to 98.7 ; that of copper, to 99.5 ; platinum, to 99.6; and palladium to 99.6. Simultaneously, a copper cake of an improved composition, namely, (\%) 57-62 Cu, <3 Ni, 8-11 Fe, was produced. The arsenic content in the copper cake was decreased from $1.5-2$ to $0.15-0.3 \%$.

(5) The largest projects implemented in NNH are as follows: stage-by stage implementation of a mattefree technology with simultaneous modification of the matte line for processing converter matte; the development of a jarosite technology of iron deposition from a nickel solution, which decreased the irreversible losses of nonferrous and precious metals with a waste iron cake as much as possible (the losses of nickel and cobalt were decreased by 11 times; those of copper, by 23 times; platinum, by 16 abs \%; palladium, by 10 abs \%; rhodium, by 9 abs \%; and gold, by 12 abs \%); and the building and introduction of carbonate processing, which allowed the production of nickel cathodes to be increased.

(6) As a result of the measures taken to redistribute raw materials, the mattes of slag-cleaning furnaces, which contained $35-40 \% \mathrm{Fe}$, were moved to OAO Kol'skaya GMK.

(7) One of the key factors of the economic efficiency of the matte-free technology was a decrease in the specific consumption of the main reagents (oxygen, air, sulfuric acid) and the energy resources used for the manufacture of nickel products.

\section{REFERENCES}

1. L. V. Igrevslaya, Nickel Industry of Finland in the Hands of Norilsk Nickel. http://www.mineral.ru/Analytics/ worldevents/111/87/index.html.
2. T. Morgan, Purchase of the Plant in Harjavalta-Bull's Eye (2007). http://www.infogeo.ru/metalls/press/?act= show\&rev $=3560$.

3. A. N. Burukhin, T. V. Galantseva, M. N. Naftal', et al., "Modification of nickel-refining production," Tsvetn. Met., No. 6, 56-61 (2000).

4. K. Knuutila, S.-E. Hultholm, B. Sahen, and L. Rosenback, "New nickel process increasing production at 'Outokumpu Harjavalta Metals Oy'” in Proceedings of ALTA 1997: Nickel/Cobalt Pressure Leaching \& Hydrometallurgy Forum (Perth, 1997).

5. A. Parviainen, "Harjavalta: five decades with metallurgical innovations," Tsvetn. Met., No. 10, 18-21 (1996).

6. S. S. Jounela, "Menetelmk sulfidisten, vaikeasti sulatet-tavien nikkelirikasteiden tai vastaavien seosten hyodyntamiseksi," FI Patent 93974, 1995. https://patents.google.com/patent/FI93974B/fi.

7. I. Koio, T. Myakinen, and P. Khanniala, "Direct outotec nickel (DON) smelting process: high metal recovery at the minimum outbursts," Tsvetn. Met., June, 76-80 (2001).

8. I. D. Reznik, G. P. Ermakov, and Ya. M. Shneerson, Nickel (Nauka Tekhnologii, Moscow, 2003), Vol. 3.

9. M. N. Naftal', R. D. Shestakova, T. V. Galantseva, et al., "Technology of leaching high-copper converter matte," Tsvetn. Met., No. 6, 44-49 (2000).

10. D. T. Khagazheev, B. G. Gulevich, A. N. Burukhin, et al., "Development of the optimum strategy of development AO Noril'sk metallurgical works up to 2005," Tsvetn. Met., No. 10-11, 20-25 (1998).

11. S. S. Naboichenko, Ya. M. Shneerson, M. I. Kalashnikova, and L. V. Chugaev, in Pressure Hydrometallurgy of Nonferrous Metals (GOU VPO UGTU-UPI, Yekaterinburg, 2009), Vol. 2, pp. 162-169.

12. M. N. Naftal', A. F. Petrov, R. D. Shestakova, et al., "Method for the processing of melted sulfide coppernickel materials containing cobalt, iron, and platinumgroup metals," RF Patent 2252270, 2005.

13. M. N. Naftal', V. A. Polosukhin, R. D. Shestakova, et al., "Nadezhdinsk metallurgical plant - new horizons of development," Tsvetn. Met., No. 6, 53-55 (2001).

14. R. Virrankoski and Yu. Vakhtola, "Cooperation with concern Outokumpu," Tsvetn. Met., No. 6, 68-69 (2000).

15. Annual Report of OAO GMK Norilsk Nickel in 2012. https://ar2016.nornik.ru/download/additional-materials/ 2012/ru_2012-armual-report.pdf.

16. GMK Norilsk Nickel Summarizes the Results of Operation of Harjavalta. http://www.nornik.ru/press/news/3456/.

17. Papers about Norilsk Nickel. http://www.nornik.ru/ press/publications/1932/.

Translated by K. Shakhlevich 